\title{
Article \\ Children's Greenness Exposure and IQ-Associated DNA Methylation: A Prospective Cohort Study
}

\author{
Kyung-Shin Lee ${ }^{1,2,+} \mathbb{D}$, Yoon-Jung Choi ${ }^{1,2,+}{ }^{\mathbb{D}}$, Jin-Woo Cho ${ }^{3}$, Sung-Ji Moon ${ }^{1}$, Youn-Hee $\operatorname{Lim}^{1,4}{ }^{\mathbb{D}}$, \\ Johanna-Inhyang Kim ${ }^{5} \mathbb{D}^{\text {, }}$ Young-Ah Lee ${ }^{6}$, Choong-Ho Shin ${ }^{6} \mathbb{D}^{\text {, Bung-Nyun Kim }}{ }^{7, *}$ and Yun-Chul Hong ${ }^{1,2,8, *}$
}

1 Department of Preventive Medicine, Seoul National University College of Medicine, Seoul 03080, Korea; kslee0116@snu.ac.kr (K.-S.L.); pastelorange2012@gmail.com (Y.-J.C.); kajaman3@snu.ac.kr (S.-J.M.); limyounhee@gmail.com (Y.-H.L.)

2 Environmental Health Center, Seoul National University College of Medicine, Seoul 03080, Korea

3 Department of Statistics, University of Pittsburgh, Pittsburgh, PA 15260, USA; kevinjwcho@pitt.edu

4 Section of Environmental Health, Department of Public Health, University of Copenhagen, 1014 Copenhagen, Denmark

5 Department of Psychiatry, Hanyang University Medical Center, Seoul 04763, Korea; iambabyvox@hanmail.net

6 Department of Pediatrics, Seoul National University Children's Hospital, Seoul National University College of Medicine, Seoul 03080, Korea; nina337@snu.ac.kr (Y.-A.L.); chshinpd@snu.ac.kr (C.-H.S.)

7 Division of Children and Adolescent Psychiatry, Department of Psychiatry, Seoul National University Hospital, Seoul 03080, Korea

8 Institute of Environmental Medicine, Seoul National University Medical Research Center, Seoul 03080, Korea

* Correspondence: kbn1@snu.ac.kr (B.-N.K.); ychong1@snu.ac.kr (Y.-C.H.)

$\dagger$ These authors contributed equally to this work.

check for updates

Citation: Lee, K.-S.; Choi, Y.-J.; Cho, J.-W.; Moon, S.-J.; Lim, Y.-H.; Kim, J.-I.; Lee, Y.-A.; Shin, C.-H.; Kim, B.-N.; Hong, Y.-C. Children's Greenness Exposure and IQ-Associated DNA Methylation: A Prospective Cohort Study. Int. J. Environ. Res. Public Health 2021, 18, 7429. https:// doi.org/10.3390/ijerph18147429

Academic Editor: Jitse P. van Dijk

Received: 25 May 2021

Accepted: 5 July 2021

Published: 12 July 2021

Publisher's Note: MDPI stays neutral with regard to jurisdictional claims in published maps and institutional affiliations.

Copyright: (c) 2021 by the authors Licensee MDPI, Basel, Switzerland. This article is an open access article distributed under the terms and conditions of the Creative Commons Attribution (CC BY) license (https:// creativecommons.org/licenses/by/ $4.0 /)$

\begin{abstract}
Epigenetics is known to be involved in regulatory pathways through which greenness exposure influences child development and health. We aimed to investigate the associations between residential surrounding greenness and DNA methylation changes in children, and further assessed the association between DNA methylation and children's intelligence quotient (IQ) in a prospective cohort study. We identified cytosine-guanine dinucleotide sites (CpGs) associated with cognitive abilities from epigenome- and genome-wide association studies through a systematic literature review for candidate gene analysis. We estimated the residential surrounding greenness at age 2 using a geographic information system. DNA methylation was analyzed from whole blood using the HumanMethylationEPIC array in 59 children at age 2. We analyzed the association between greenness exposure and DNA methylation at age 2 at the selected CpGs using multivariable linear regression. We further investigated the relationship between DNA methylation and children's IQ. We identified $8743 \mathrm{CpGs}$ associated with cognitive ability based on the literature review. Among these CpGs, we found that $25 \mathrm{CpGs}$ were significantly associated with greenness exposure at age 2, including cg26269038 (Bonferroni-corrected $p \leq 0.05$ ) located in the body of SLC6A3, which encodes a dopamine transporter. DNA methylation at cg26269038 at age 2 was significantly associated with children's performance IQ at age 6. Exposure to surrounding greenness was associated with cognitive ability-related DNA methylation changes, which was also associated with children's IQ. Further studies are warranted to clarify the epigenetic pathways linking greenness exposure and neurocognitive function.
\end{abstract}

Keywords: greenness; epigenetics; DNA methylation; intelligence quotient; cytosine-guanine dinucleotide sites

\section{Introduction}

Exposure to greenness in urban areas is estimated to have physiological and psychosocial health benefits in children [1-5]. Urban greenness can contribute to reducing the harmful effects of urbanization [6], including reducing exposure to environmental toxicants [7] and noise [8], increasing the level of physical activity [9,10], and enhancing social 
cohesion [11] in children. However, the biological mechanisms underlying the association between greenness exposure and desirable health effects remain unclear.

Many epidemiological studies have shown that an adverse intrauterine environment, including smoking [12-14], chemical exposures [15-18], ambient air pollution [19,20], and stress [21,22], may result in epigenetic perturbations of the developing fetus and can be associated with an increased risk of adverse health outcomes in later life. Additionally, exposure to heavy metals in early childhood (ages 1-4 years) was significantly associated with epigenetic change such as H19 hypermethylation, which may contribute to growth and metabolic diseases [23]. Hence, DNA methylation may be a possible mechanism by which early life environmental factors contribute to an increased risk of diseases in later life [24,25]. In addition, epigenetic modifications, such as DNA methylation, are susceptible to genetic and environmental factors and may provide insights into individual differences in health outcomes [26]. Epigenetic change is hypothesized to be a regulatory pathway through which exposure to greenness in early childhood may influence child development and health.

However, few studies have assessed the association between greenness exposure and changes in DNA methylation. Xu et al. (2021) showed an association between greenness exposure and gene and their interactions on blood-derived DNA methylation in 479 adult females [27]. They found greenness-associated DNA methylation changes of cytosineguanine dinucleotide $(\mathrm{CpG})$ sites at genes related to various human diseases such as mental disorders, neoplasms, nutritional and metabolic diseases [27]. The CNP gene at cg04720477 was strongly associated with greenness exposure and encodes a protein that has been related to low expression in brain tissue of schizophrenic [28] and depressive patients [29]. These results suggest that high greenness may be related to elevated CNP expression due to reduced methylation of this gene in female adults [27]. However, this study had a cross-sectional design, and so it was unable to determine whether DNA methylation plays a role in the association between improved mental health and exposure to greenness. In addition, they did not estimate the epigenetic impact of greenness on clinical outcomes.

Previously, we found that residential greenness was associated with IQ in the Environment and Development of Children (EDC) cohort study of 189 children [30]. We suggest that postnatal greenness exposure is more strongly associated with IQ in children than prenatal exposure to greenness. Cognitive skills are a strong predictor of a wide range of later life outcomes [31]. We hypothesized that residential greenness in early childhood may be associated with epigenetic alterations and that these alterations may influence later childhood cognitive outcomes. Using a sub-study of 59 children with DNA methylation data, we sought to evaluate the association between residential greenness exposure and DNA methylation changes reported from genome-wide association studies (GWAS) and epigenome-wide association studies (EWAS) of cognitive ability in children in a hypothesisdriven approach. We then investigated the association between the DNA methylation changes, which were significantly associated with greenness exposure, and children's IQ in the prospective EDC cohort.

\section{Materials and Methods}

\subsection{Study Population}

Our research was based on a subset of the EDC study cohort, an ongoing prospective cohort study designed to evaluate the association between prenatal and postnatal environmental exposures and physical or cognitive development. Detailed information on the study design has been described elsewhere [32]. Briefly, a total of 726 eligible pregnant women from eight local hospitals in Seoul and Gyeonggi province of South Korea were enrolled from August 2008 to July 2010. We collected urine and blood samples to estimate exposure to environmental factors during the second trimester of pregnancy. A total of 425 children aged 2 years and 574 children aged 6 years at enrolment were followed up. DNA methylation analysis was conducted in a sub-study of 59 participants using blood 
samples collected at the age of 2 years. The study protocol, including ethical approval and participant consent was reviewed and approved by the Institutional Review Board of the Seoul National University Hospital (IRB No. C-1201-010-392).

\subsection{Systematic Review of Literature and Selection of Candidate Cytosine-Guanine Dinucleotide Sites}

As we were specifically interested in the question of whether DNA methylation mediates the effects of exposure to greenness on children's IQ, we targeted CpG sites that were more likely to be involved in cognitive ability instead of scanning the whole epigenome. For the selection of previous EWAS or GWAS on association with cognitive abilities, we searched PUBMED and EMBASE on April 1, 2021, using keywords ("epigenome-wide association study" or "genome-wide association study") and ("intelligence" or "cognitive ability" or "cognitive development") from titles or abstracts. The selection criteria were EWAS or GWAS regarding cognitive ability in healthy children or adults. From previous EWAS or GWAS that investigated the association between DNA methylation and cognitive ability in healthy children or adults, we identified CpG sites associated with cognitiveability-related parameters (Figure 1). In the GWAS, single nucleotide polymorphisms (SNPs) associated with cognitive ability were identified, and then the genes annotated to these SNPs were identified. The CpG sites associated with these genes were pooled using the Database for Annotation, Visualization, and Integrated Discovery (DAVID, http:/ / david.abcc.ncifcrf.gov/home.jsp). We added IQ-related genes from bibliographyies, in which the genes were identified through enrichment analyses.

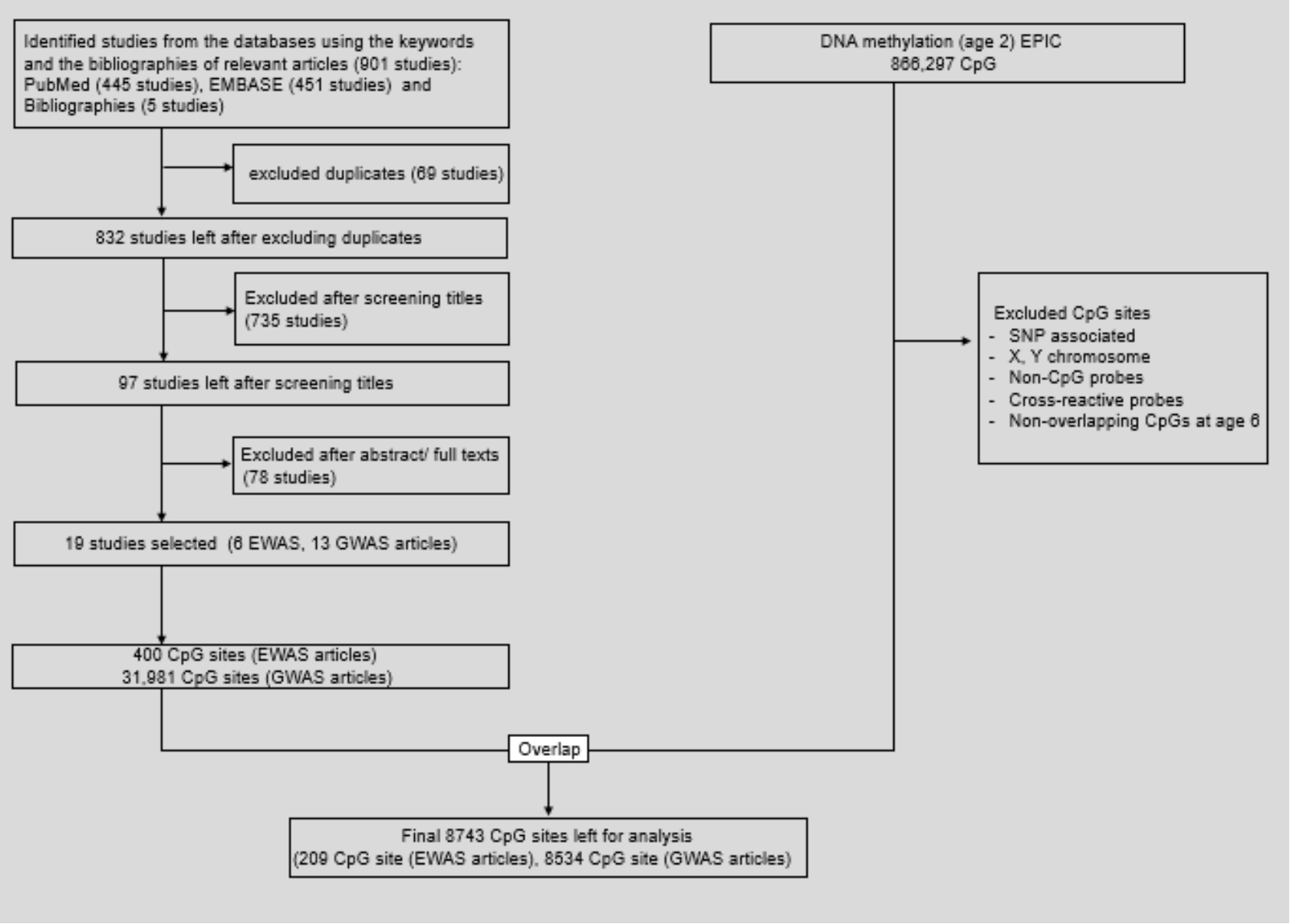

Figure 1. Workflow for model building for selecting cognitive abilities based on a systematic literature review. 


\subsection{Measurement of Residential Surrounding Greenness}

To estimate exposure to greenness, the residential addresses were collected at the age of 2 years. The surrounding greenness was recorded using Landsat image data from the IKONOS satellite images [33] and Korean Arirang satellite images taken by the Environmental Geographic Information Service of the Ministry of the Environment (https:// egis.me.go.kr/main.do). To estimate exposure to greenness, densities of greenness were calculated within buffer radii of 100, 500, 1000, 1500, and $2000 \mathrm{~m}$ of each child's residential address. We then determined the percentage of greenness (density) from the area within each buffer radius. We separately analyzed two types of greenness, namely, natural greenness, forest or natural grassland, and built greenness, including artificial grassland, urban parks, and street trees. We did not analyze the effect of natural greenness within buffer radii of both 100 and $500 \mathrm{~m}$ because natural greenness was barely observed within these ranges.

\subsection{Measurement of DNA Methylation}

2.4.1. Assessment of DNA Methylation at Age 2 in the Environment and the Development of Children Study Cohort

We performed genome-wide DNA methylation analyses using the whole blood samples of 59 2-year-old children as described in an earlier study [34]. Briefly, DNA samples were tested for quality using a NanoDrop ${ }^{\circledR}$ ND-1000 UV-VIS spectrophotometer (Thermo Fisher Scientific, Wilmington, DE, USA). Electrophoresis was performed using $1 \%$ agarose gel, and samples with genomic DNA (gDNA) were diluted to $50 \mathrm{ng} / \mu \mathrm{L}$ based on Quanti-iT Picogreen quantification (Thermo Fisher Scientific, Wilmington, DE, USA). The gDNA samples (minimum $500 \mathrm{ng}$ ) were diluted, then bisulfite-converted using the Zymo EZ DNA methylation kit (Zymo Research, Irvine, CA, USA), and the DNA was then amplified to be used on the DNA BeadChip. At age 2, we used the Illumina Infinium Human MethylationEPIC BeadChip, which yielded 850,000 CpG sites (Illumina, San Diego, CA, USA). Images were read by the Illumina BidArray Reader, and the image intensities were extracted using the Illumina GenomeStudio software. Microarrays were handled by Macrogen Co. (Seoul, Korea). For functional annotation analysis, we used the DAVID (david.abcc.ncifcrf.gov) tool.

\subsubsection{Quality Control of Methylation Data}

Filtered data were normalized using the Beta Mixture Quantile (BMIQ) method [35]. With the Human MethylationEPIC BeadChip (850K), a total of 866,297 CpG sites were extracted for the raw data, and $609 \mathrm{CpG}$ sites $(0.07 \%)$ which had detection $p$-value $\geq 0.05$ across more than $25 \%$ of all samples were excluded from analysis. Thus, 865,688 CpG sites were left for analysis. We also filtered $\mathrm{CpG}$ sites according to the following exclusion criteria: (a) SNP-associated CpG sites defined as 0 or 1 base pair near SNP loci or minor allele frequency (MAF) $>5 \%$ (213,660 CpG sites); (b) CpG sites that corresponded to the $\mathrm{X}$ or Y chromosome (19,627 CpG sites); (c) CpG sites corresponding to non-CpG loci (3627 CpG sites).; (d) cross-reactive CpG sites (42,558 CpG sites). We were finally left with 256,866 CpG sites which overlapped with the available epigenome data of 6-year-old children for further analysis. We also excluded multimodal CpG sites if they appeared in statistically significant CpG sites, which were identified using the dip test statistic for multimodality, which was calculated using the R package diptest module [36].

\subsection{Measurement of Intelligence Quotient in Children}

The IQ of the 6-year-old children was measured using the Korean Educational Developmental Institute's Wechsler Intelligence Scale for Children [37]. Higher scores indicated higher IQ. Two subsets were measured: verbal IQ, based on the sum of the test results for vocabulary and arithmetic intelligence, and performance IQ, based on the sum of the tests for picture arrangement and block design [38]. 


\subsection{Measurement of Other Exposure Variables}

We collected demographic information on the children and their mothers by means of interviews using structured questionnaires. Covariates were selected based on a literature review $[27,30]$. The covariates used to analyze the association between greenness and DNA methylation were mother's age at pregnancy (years), mother's educational level (middle school graduate, high school graduate, college graduate, or graduate school attendance), children's exposure to environmental tobacco smoke (ETS) at age 2 (yes or no), children's sex (male or female), children's age at follow-up (months, continuous variable), children's body mass index (BMI) $\left(\mathrm{kg} / \mathrm{m}^{2}\right.$, continuous variable), and cell type fractions (continuous variables). The cell type fractions in blood samples were calculated using the $\mathrm{R}$ package minfy module [39]. To estimate the percentage of CD8 + T cells, CD4 + T cells, natural killer cells, B cells, monocytes, and neutrophils, adults' leukocyte reference dataset was used [40]. We also used the covariates for analyzing the association between DNA methylation and children's IQ at age 6, including children's age at follow-up, children's BMI, maternal age during pregnancy, maternal education level, exposure to ETS at age 2, maternal IQ, and children's sex. The short form of the Korean Wechsler Adult Intelligence Scale was used to assess maternal IQ at the time of their children's follow-up visit at the age of 6 [41].

\subsection{Statistical Analysis}

We compared the demographic and clinical characteristics of the sub-study population to the population of the EDC study that was not included in our study using the Student's $t$-test (for continuous variables) or chi-square test (for categorical variables) (Table 1). We used batch-effect-adjusted DNA methylation data obtained using the R package ComBat module to adjust different distributions according to chips and positions from the array data [42]. This process uses an empirical Bayes method to adjust batch effects in small sample sizes. We performed multivariable linear regression to determine the relationship between exposure to greenness at age 2 and cognitive-ability-related DNA methylation at age 2, adjusting for monthly age at follow-up, BMI at age 2, maternal education level, cell type fractions (CD8 + T cells, CD4 + T cells, natural killer cells, B cells, monocytes, and neutrophils), ETS, maternal age at delivery, and child's sex. Using the CpG sites significantly associated with exposure to greenness at age 2 , we tested the association of DNA methylation levels at these CpG sites with total, verbal, and performance IQ scores at age 6, adjusting for maternal age during pregnancy, exposure to ETS at age 2, maternal IQ, and children's sex using the selection criteria to select the best model by comparing the Akaike Information Criterion (AIC) [43]. Using the CpG sites significantly associated with exposure to greenness at age 2, we tested the association of DNA methylation levels at these CpG sites with total, verbal, and performance IQ scores at age 6 in multiple linear regression models, adjusting for maternal age during pregnancy, exposure to ETS at age 2, maternal IQ, and children's sex using the selection criteria to select the best model by comparing the AIC. To account for multiple testing, we used a Bonferroni-corrected $p$-value $\leq 0.05$ for statistical significance. Pathway enrichment analysis was performed using the ReactomePA R package [44]. Enrichment analysis of functional terms revealed the Reactome pathway enriched in the genes identified as significant from their association between greenness exposure and cognitive-ability-related CpG sites (Bonferroni-corrected $p \leq 0.05$ ). All statistical analyses were performed using SAS version 9.4 (SAS Institute Inc., Cary, NC, USA) and R software version 3.6.0 (R Foundation for Statistical Computing, Vienna, Austria). 
Table 1. Characteristics of participants at age 2 in sub-study compared to total EDC population.

\begin{tabular}{|c|c|c|c|c|}
\hline \multirow{2}{*}{\multicolumn{2}{|c|}{ Variables }} & $\begin{array}{l}\text { Study Population } \\
\qquad(n=59)\end{array}$ & $\begin{array}{l}\text { EDC Population Excluded } \\
\text { from the Study } \\
(n=366)\end{array}$ & \multirow[t]{2}{*}{$p$-Value } \\
\hline & & $n(\%)$ or Mean $\pm \mathrm{SD}$ & $n(\%)$ or Mean \pm SD & \\
\hline \multicolumn{2}{|c|}{ Maternal age at pregnancy (years) } & $31.10 \pm 3.79$ & $31.68 \pm 3.60$ & 0.256 \\
\hline \multicolumn{2}{|c|}{ Children's age (months) } & $23.32 \pm 0.77$ & $23.31 \pm 0.76$ & 0.922 \\
\hline \multicolumn{2}{|c|}{ Children's BMI at age 2} & $16.57 \pm 1.20$ & $16.48 \pm 1.44$ & 0.666 \\
\hline \multicolumn{2}{|c|}{ Maternal IQ } & $117.8 \pm 11.5$ & $115.8 \pm 11.1$ & 0.248 \\
\hline \multirow{3}{*}{ Maternal education level } & High school graduate & $9(15.25)$ & 70 (19.13) & \multirow{3}{*}{0.669} \\
\hline & College graduate & $42(71.19)$ & $257(70.22)$ & \\
\hline & Graduate school & $8(13.56)$ & $39(10.66)$ & \\
\hline \multirow{2}{*}{ Prenatal exposure to ETS } & Yes & $14(23.73)$ & $89(24.32)$ & \multirow{2}{*}{0.922} \\
\hline & No & $45(76.27)$ & $277(75.68)$ & \\
\hline \multirow{2}{*}{ Children's sex } & Girl & $30(50.85)$ & $172(46.99)$ & \multirow{2}{*}{0.582} \\
\hline & Boy & $29(49.15)$ & $194(53.01)$ & \\
\hline \multirow{5}{*}{$\begin{array}{l}\text { Percentage of total greenness } \\
\text { at the home address at age } 2\end{array}$} & $100 \mathrm{~m}$ & $17.67 \pm 12.8$ & $19.82 \pm 14.0$ & 0.276 \\
\hline & $500 \mathrm{~m}$ & $18.71 \pm 11.1$ & $21.36 \pm 13.9$ & 0.108 \\
\hline & $1000 \mathrm{~m}$ & $19.95 \pm 11.2$ & $23.61 \pm 13.6$ & 0.028 \\
\hline & $1500 \mathrm{~m}$ & $23.63 \pm 12.8$ & $24.77 \pm 12.9$ & 0.529 \\
\hline & $2000 \mathrm{~m}$ & $25.29 \pm 13.4$ & $26.32 \pm 12.7$ & 0.569 \\
\hline \multirow{3}{*}{ IQ at age 6} & Total IQ & $107.4 \pm 13.7$ & $110.6 \pm 12.5$ & 0.088 \\
\hline & Verbal IQ & $21.08 \pm 5.03$ & $20.81 \pm 7.06$ & 0.732 \\
\hline & Performance IQ & $23.47 \pm 5.10$ & $22.91 \pm 7.26$ & 0.487 \\
\hline
\end{tabular}

Abbreviations: EDC, Environment and the Development of Children; SD, standard deviation; ETS, environmental tobacco smoke; BMI, body mass index; IQ, intelligence quotient.

\section{Results}

\subsection{Participant Characteristics}

Table 1 presents the participant characteristics. The mean maternal age at delivery was 31.10 years (standard deviation (SD): 3.79 years). The mean age and BMI of children were 23.32 months (SD: 0.77 months) and $16.57 \mathrm{~kg} / \mathrm{m}^{2}$ (SD: $1.20 \mathrm{~kg} / \mathrm{m}^{2}$ ), respectively. The mean maternal IQ was 117.8 (SD: 11.5). The percentages of mothers who received less than a high school education and more than a graduate school education were $15.25 \%$ and $13.56 \%$, respectively. A total of $23.73 \%$ of the participants were in a group with positive exposure to ETS during pregnancy. There were similar numbers of girls and boys in the study (30 and 29 , respectively). The percentage of greenness exposure at age 2 within 100-2000 m was ranged from $17.67 \%$ to $25.29 \%$. The mean total, verbal, and performance IQ scores at age 6 were 107.40 (SD: 13.70), 21.08 (SD: 5.03), and 23.47 (SD: 5.10), respectively. In addition, we found that the characteristics of our study subcohort were not significantly different from those of the participants in the entire EDC cohort, except for exposure to greenness at age 2 in $1000 \mathrm{~m}$ buffer of residential address.

\subsection{Systematic Literature Review}

We found a total of 896 studies (445 studies in PubMed and 451 studies in EMBASE) after applying the keywords search strategy described in Table S1. Five studies were included in the bibliographic search. After excluding duplicated studies $(n=64), 97$ studies were included for screening by title, and 735 studies were excluded because they were studies of cognitive aging or cognitive disease or were not primary investigation. We 
further excluded irrelevant articles such as invalid study designs or cognitive outcomes, such as mathematics, school performance, or memory, finally leaving a total of 19 articles (Figure 1).

A total of 400 CpG sites were selected from 6 EWAS [26,45-49]. Additionally, a total of 31,981 CpG sites were selected, which were annotated to 835 genes reported from 13 GWAS after excluding duplicate genes [50-62]. As a result, 8743 CpG sites were finally selected (Tables S2 and S3).

\subsection{Association between Greenness Exposure and DNA Methylation}

A total of $209 \mathrm{CpG}$ sites from the EWAS and 8,534 CpG sites from the GWAS were analyzed in our study. We found that 25 cognitive-ability-related $\mathrm{CpG}$ sites were significantly associated with greenness exposure at age 2 (8 CpG sites from EWAS and $17 \mathrm{CpG}$ sites from GWAS) (Table 2) in total greenness in buffers of 100-2000 m, natural greenness in buffers of 1000-2000 m, and built greenness in buffers of $1000 \mathrm{~m}$ and $1500 \mathrm{~m}$, with a significance criterion for Bonferroni-corrected $p$-values $<0.05$ (Table 2).

Table 2. The significant relationship between greenness exposure and selected DNAm at age $2^{\dagger}$.

\begin{tabular}{|c|c|c|c|c|c|c|}
\hline Origin Study & $\begin{array}{c}\text { Greenness } \\
\text { Type }\end{array}$ & Buffer & CpG & Gene & $\begin{array}{l}\text { Difference } \\
(95 \% \text { CI })^{\S}\end{array}$ & $p$-Value \\
\hline \multirow{10}{*}{$\begin{array}{l}\text { EWAS } \\
\text { Study }\end{array}$} & \multirow{6}{*}{ Total } & $100 \mathrm{~m}$ & cg13092901 & TYMP & $0.021(0.012,0.029)$ & $2.0 \times 10^{-5}$ \\
\hline & & \multirow{4}{*}{$500 \mathrm{~m}$} & cg04789403 & $N A$ & $0.031(0.015,0.047)$ & $1.1 \times 10^{-4}$ \\
\hline & & & $\operatorname{cg} 07266431$ & CDK6 & $0.028(0.015,0.040)$ & $1.9 \times 10^{-4}$ \\
\hline & & & $\operatorname{cg} 13599020$ & SAMD3 & $0.026(0.014,0.039)$ & $1.9 \times 10^{-4}$ \\
\hline & & & $\operatorname{cg} 27492942$ & CISD3 & $0.029(0.013,0.045)$ & $1.7 \times 10^{-4}$ \\
\hline & & $1000 \mathrm{~m}$ & cg00252813 & GAPDH & $0.013(0.006,0.020)$ & $6.1 \times 10^{-5}$ \\
\hline & \multirow{2}{*}{ Natural } & \multirow{2}{*}{$1000 \mathrm{~m}$} & $\operatorname{cg} 00252813$ & GAPDH & $0.013(0.007,0.019)$ & $5.8 \times 10^{-5}$ \\
\hline & & & cg04789403 & $N A$ & $0.020(0.010,0.030)$ & $7.7 \times 10^{-5}$ \\
\hline & \multirow{2}{*}{ Built } & $1000 \mathrm{~m}$ & $\operatorname{cg} 16594502$ & $N A$ & $0.015(0.008,0.022)$ & $9.4 \times 10^{-5}$ \\
\hline & & $1500 \mathrm{~m}$ & cg25189904 & GNG12 & $0.028(0.013,0.044)$ & $2.3 \times 10^{-4}$ \\
\hline \multirow{12}{*}{$\begin{array}{l}\text { GWAS } \\
\text { Study }\end{array}$} & \multirow{12}{*}{ Total } & \multirow{3}{*}{$100 \mathrm{~m}$} & $\operatorname{cg} 26269038$ & $S L C 6 A 3$ & $-0.011(-0.015,-0.007)$ & $3.2 \times 10^{-8}$ \\
\hline & & & $\operatorname{cg} 14464361$ & $A G A P 1$ & $-0.023(-0.032,-0.016)$ & $2.2 \times 10^{-6}$ \\
\hline & & & $\operatorname{cg} 21175642$ & CELSR3 & $0.013(0.007,0.016)$ & $3.4 \times 10^{-6}$ \\
\hline & & \multirow{4}{*}{$1000 \mathrm{~m}$} & cg23651585 & AUTS2 & $-0.039(-0.056,-0.024)$ & $9.9 \times 10^{-7}$ \\
\hline & & & cg27636559 & EFTUD1 & $0.007(0.004,0.009)$ & $1.2 \times 10^{-6}$ \\
\hline & & & $\operatorname{cg} 27609819$ & PLCL1 & $-0.027(-0.038,-0.015)$ & $2.3 \times 10^{-6}$ \\
\hline & & & $\operatorname{cg} 16296679$ & WBP2NL & $0.015(0.009,0.022)$ & $2.9 \times 10^{-6}$ \\
\hline & & \multirow{2}{*}{$1500 \mathrm{~m}$} & cg17146029 & AUTS2 & $0.010(0.007,0.013)$ & $1.0 \times 10^{-7}$ \\
\hline & & & cg00809988 & ELAVL2 & $-0.006(-0.009,-0.003)$ & $1.5 \times 10^{-7}$ \\
\hline & & \multirow{3}{*}{$2000 \mathrm{~m}$} & $\operatorname{cg} 17146029$ & AUTS2 & $0.009(0.006,0.012)$ & $3.9 \times 10^{-8}$ \\
\hline & & & cg00809988 & ELAVL2 & $-0.004(-0.008,-0.002)$ & $3.2 \times 10^{-7}$ \\
\hline & & & cg03367519 & PDE4D & $-0.005(-0.008,-0.002)$ & $3.3 \times 10^{-6}$ \\
\hline
\end{tabular}


Table 2. Cont.

\begin{tabular}{|c|c|c|c|c|c|c|}
\hline Origin Study & $\begin{array}{c}\text { Greenness } \\
\text { Type }\end{array}$ & Buffer & CpG & Gene & $\begin{array}{l}\text { Difference } \\
(95 \% \mathrm{CI})^{\S}\end{array}$ & $p$-Value \\
\hline & \multirow{15}{*}{ Natural } & \multirow{3}{*}{$1000 \mathrm{~m}$} & cg27609819 & PLCL1 & $-0.029(0.039,-0.020)$ & $3.7 \times 10^{-8}$ \\
\hline & & & $\operatorname{cg} 23651585$ & AUTS2 & $-0.043(-0.059,-0.027)$ & $7.4 \times 10^{-8}$ \\
\hline & & & $\operatorname{cg} 27636559$ & EFTUD1 & $0.007(0.005,0.009)$ & $2.2 \times 10^{-7}$ \\
\hline & & \multirow{6}{*}{$1500 \mathrm{~m}$} & $\operatorname{cg} 23651585$ & AUTS2 & $-0.041(-0.055,-0.025)$ & $2.6 \times 10^{-7}$ \\
\hline & & & $\operatorname{cg} 23159678$ & NOVA1 & $0.009(0.004,0.014)$ & $1.9 \times 10^{-6}$ \\
\hline & & & cg05016953 & $S L C 6 A 4$ & $-0.004(-0.006,-0.001)$ & $2.2 \times 10^{-6}$ \\
\hline & & & $\operatorname{cg} 27609819$ & PLCL1 & $-0.025(-0.036,-0.016)$ & $2.2 \times 10^{-6}$ \\
\hline & & & $\operatorname{cg} 03367519$ & $P D E 4 D$ & $-0.005(-0.007,-0.002)$ & $2.9 \times 10^{-6}$ \\
\hline & & & cg00809988 & ELAVL2 & $-0.005(-0.007,-0.002)$ & $5.3 \times 10^{-6}$ \\
\hline & & \multirow{6}{*}{$2000 \mathrm{~m}$} & $\operatorname{cg} 17146029$ & AUTS2 & $0.010(0.006,0.012)$ & $1.8 \times 10^{-6}$ \\
\hline & & & $\operatorname{cg} 23651585$ & AUTS2 & $-0.046(-0.064,-0.026)$ & $1.9 \times 10^{-6}$ \\
\hline & & & $\operatorname{cg} 11176256$ & BAIAP2 & $0.016(0.010,0.023)$ & $3.5 \times 10^{-6}$ \\
\hline & & & $\operatorname{cg} 05897638$ & PROS1 & $-0.007(-0.010,-0.003)$ & $5.1 \times 10^{-6}$ \\
\hline & & & cg00809988 & ELAVL2 & $-0.005(-0.009,-0.002)$ & $5.5 \times 10^{-6}$ \\
\hline & & & $\operatorname{cg} 12414502$ & $B T N 2 A 1$ & $0.010(0.006,0.012)$ & $5.6 \times 10^{-6}$ \\
\hline & \multirow{2}{*}{ Built } & \multirow{2}{*}{$1500 \mathrm{~m}$} & $\operatorname{cg} 19258882$ & $E R B B 3$ & $0.024(0.015,0.032)$ & $4.6 \times 10^{-6}$ \\
\hline & & & $\operatorname{cg} 18311871$ & PTPRN2 & $0.081(0.047,0.115)$ & $3.2 \times 10^{-6}$ \\
\hline
\end{tabular}

Abbreviations: CpG site location based on Illumina annotation, derived from the University of California, Santa Cruz (UCSC), adjusted for children's age, children's BMI, maternal education level, cell type fractions (CD8 + T cells, CD4 + T cells, natural killer cells, B cells, monocytes, and neutrophils), environmental tobacco smoke, maternal age, and children's sex. The list was significantly associated as per Bonferroni correction $(p<0.05) .{ }^{\dagger}$ Analyzed using a linear regression model. $\S$ Change in DNA methylation level by an increase of 1 interquartile range of greenness percentage within each buffer.

\subsection{Pathway Enrichment Analysis}

We investigated potential biological functions by performing pathway enrichment analysis with the cutoff $p$-value set to 0.1 . We found the top 20 pathways, including transmission across chemical synapses, opioid signaling, and neuronal systems pathway (Figure 2A). Notably, a single pathway of neurotransmitter clearance was only significantly enriched for the SLC6A3 and SLC6A4 genes at the selected cutoff ( $p$-value was 0.05) (Table S4). SLC6A3 and SLC6A4 genes were significantly related to greenness exposure, of which SLC6A3 also showed significant associations with IQ in this study. Figure 2B shows linkages between the genes and biological functions as a network. In addition to the neurotransmitter clearance pathway, SLC6A4 and SLC6A3 were non-significantly linked via transmission across chemical synapses (adjusted $p$-value: 0.12 , respectively; Table S4). 
(A)

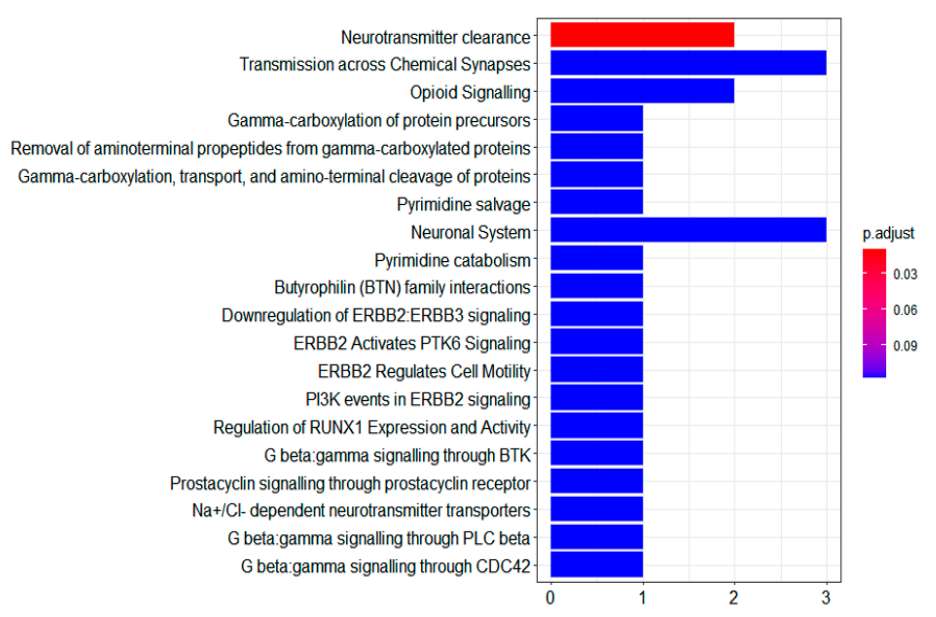

(B)

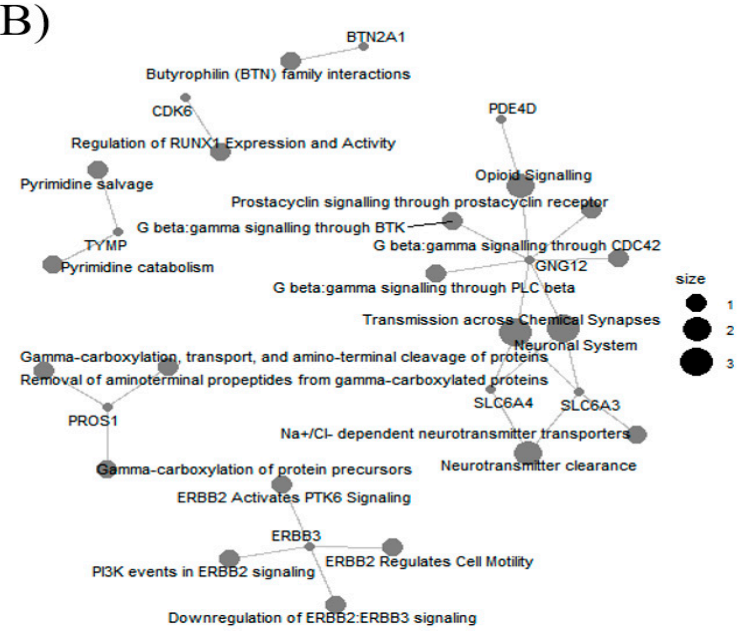

Figure 2. Reactome pathway enrichment analysis of the greenness-associated genes, which shows the top 20 pathways. (A) The enrichment scores in the Reactome pathway analysis of the greenness exposure-related genes. (B) The network of the most enriched pathways of the greenness exposure-related genes. Larger nodes represent higher enrichment scores that represent different enrichment modules.

\subsection{Association between DNA Methylation and Children's Intelligence Quotient}

The association of the methylation levels of the $25 \mathrm{CpG}$ sites at age 2 and total, verbal, and performance IQ scores at age 6 are shown in Table S5. Notably, one interquartile range (IQR) increase of the methylation level at cg26269038 was significantly associated with an increased performance IQ score at age 6 (2.89-point increase in IQ was 2.89 (95\% CI: 1.27, 4.51 ) in the adjusted models after Bonferroni correction (Table 3). However, there was no significant association between total IQ or verbal IQ and the level of DNA methylation (Table 3). In sensitive analysis, we analyzed these associations with additional covariates such as breastfeeding pattern and mother's previous smoking status in Table S6. The result was not different from the main result in Table 3. We plotted the least-squares means of the methylation level at cg26269038 by exposure to greenness as the quartile group. The percentages of greenness in the $100 \mathrm{~m}$ buffer of residential address for each participant were divided into quartiles and were then performed to determine whether individuals in the three higher quartiles differed significantly from those in the lowest quartile. The highest quartile of DNA methylation level at cg26269038 was significantly different from the lowest quartile (Figure 3).

Table 3. Association between selected CpG sites and children's Performance IQ $(n=59)$ †.

\begin{tabular}{|c|c|c|c|c|c|c|}
\hline IQ & CpG Sites & Chr & Gene & Gene Group & $\begin{array}{l}\text { Difference } \\
\text { (95\% CI) § }\end{array}$ & $p$-Value * \\
\hline Total IQ & \multirow{3}{*}{ cg26269038 } & \multirow{3}{*}{5} & \multirow{3}{*}{$S L C 6 A 3$} & \multirow{3}{*}{ Body } & $3.68(-0.90,8.26)$ & 0.115 \\
\hline Verbal IQ & & & & & $-0.66(-2.47,1.15)$ & 0.475 \\
\hline Performance IQ & & & & & $2.89(1.27,4.51)$ & 0.001 \\
\hline
\end{tabular}

* Bold was significant association using Bonferroni correction $p<0.002$. † Analyzed using a linear regression model. § Difference (95\% CI) was calculated by 1 interquartile range change in DNA methylation level at each CpG site. Adjusted for children's sex, maternal age during pregnancy, exposure to ETS, and maternal IQ. 


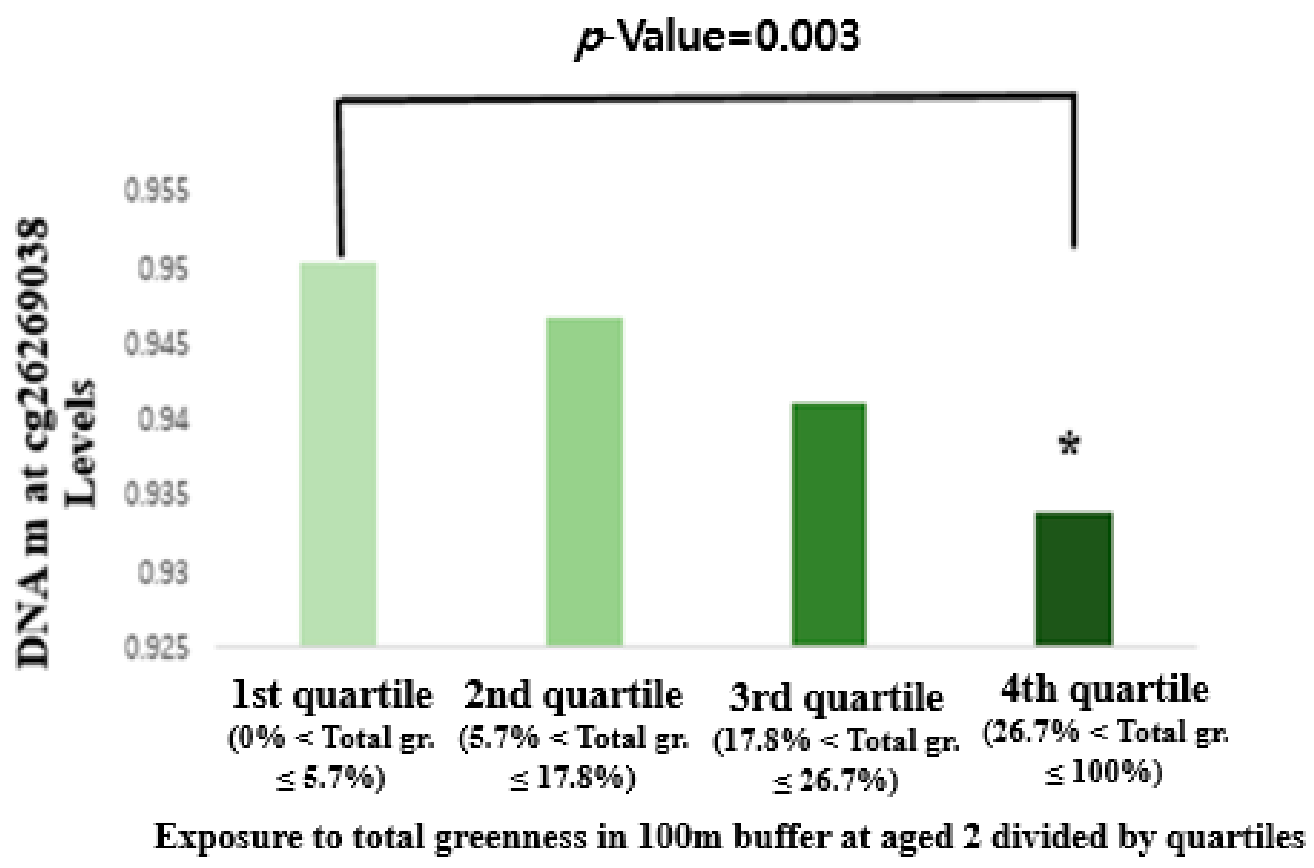

Figure 3. The LSMEANS of DNA m at cg26269038 levels in four quartiles of exposure to greenness among children. * Represents significant differences between a quartile and the lowest quartile, with $p$-values $<0.05$ considered statistically significant.

\section{Discussion}

We found that the methylation levels at 25 cognitive ability-related $\mathrm{CpG}$ sites at age 2 were significantly associated with greenness exposure during early childhood and that the methylation level at cg26269038 at age 2 (SLC6A3) was significantly associated with the performance IQ score at age 6.

Epigenetic markers, such as DNA methylation, are dynamically reprogrammed during gametogenesis and early embryo preimplantation [63,64]. Experimental evidence suggests that the epigenome of mammalian embryonic cells is more susceptible to environmental stimulation than other differentiated cells $[18,65]$ because of the abundance of de novo DNA methyltransferases in these rapidly dividing pluripotent cells $[63,64]$. The most significant DNA methylation change at cg26269038 is located in the body, intron between the third and fourth exon, of the gene solute carrier family 6 , the member 3 (SLC6A3) on the chromosome 5 . The gene encodes a dopamine transporter $(D A T)$, which is a member of the sodium- and chloride-dependent neurotransmitter transporter family, and provides rapid clearance of dopamine [66,67], which mediates the reuptake of dopamine from the synaptic cleft [68]. Cómbita et al. (2017) determined whether SLC6A3/DAT1 gene contributed to individual differences in children's self-regulation skills [69]. They evaluated self-regulation skills and cognitive tasks such as conflict processing, inhibitory control, and intelligence assessments in 127 children at ages 4 and 6 in Spain. They found that the presence of the 10 alleles of the SLC6A3 gene was related to a declining function of the dopaminergic transmission system, which was associated with poorer performance in self-regulation. Dopaminergic neurotransmission related to the $S L C 6 A 3$ and $D R D 2$ genes is reportedly associated with cognitive capacities, such as IQ, in previous studies [70-72]. Our results show that children with greater exposure to greenness had lower DNA methylation levels of the SLC6A3 gene. This region might be linked to greenness exposure and neurological development in children. However, further studies are needed to understand how these cognitiveability-related $\mathrm{CpG}$ sites are linked to greenness exposure. In line with previous findings, we found that greenness exposure in early childhood is a modifiable factor related to DNA methylation change, which was found to be associated with cognitive ability in a previous study. 
In our study, several other genes also significantly associated with greenness exposure, including PDE4D, PLCL1, GNG12, and SLC6A4, were also linked to neurotransmitter clearance in the pathway-enrichment analysis results. Signaling in the central nervous system (CNS) is terminated by the clearance of neurotransmitters from the synapse via highaffinity transporter molecules in the presynaptic membrane [73]. Accumulated evidence has shown that exposure to greenness has a positive effect on health by reducing oxidative stress [74-77]. Additionally, oxidative-stress-induced damage to the brain is likely to negatively affect normal CNS functions [78]. As these neurodegenerative disorders are related to increased environmental stressors, toxins, and oxidative stress in adults [79], brain development in children may also be linked to oxidative stress, which is reduced by greenness exposure. Similarly, oxidative stress is widely related to brain development. Recently, greenness exposure was significantly associated with reduced oxidative stress in Italian children [75]. We suggested that exposure to greenness, which was a pathway to reducing oxidative stress, may be involved in neurodevelopment.

A CpG site at cg05016953 (SLC6A4) as a serotonin transporter, which was significantly associated with greenness exposure in our study, was reported to be regulated by a $5 H T$ $T L P R$ functional polymorphism, which was significantly associated with IQ scores in a previous study [80]. However, our results showed no significant association between DNA methylation changes at cg05016953 (SLC6A4) at age 2 and children's IQ at age 6. As there is a wide distribution of the 5HTTLPR genotype by race and ethnicity [81-83], further studies should be conducted among Asian children.

The effect sizes of the association between residential greenness and DNA methylation were within $1 \sim 3 \%$. In an Australian study that investigated the association between greenness and epigenome-wide DNA methylation, the coefficients ranged from $-0.36 \%$ to $1.73 \%$ [27]. Epidemiological studies concerning the effects of environmental exposures typically show small effect sizes. For example, the differences in DNA methylation reported between exposed vs. unexposed groups are generally on the scale of $2-10 \%$, and in some cases, even smaller differences have been observed [84]. It has been reported that for every $1 \%$ change in methylation at the differentially methylated region at IGF2, a halving or doubling of IGF2 transcription was observed [85]. Although such a few percent change in DNA methylation appears as a small effect size, it is only so in the perspective of the population of cells. At a single-cell level, a CpG site is either methylated (100\%), hemimethylated $(50 \%)$, or non-methylated $(0 \%)$, and such a difference could have substantial effects on cell functions, including gene regulation [84].

Exposure to different types of greenness has been shown to have different effects on children's health. A previous study found a strong association between exposure to built greenness, but not natural greenness, and children's IQ at age 6 [30]. However, DNA methylation changes were more significantly associated with natural greenness at age 2. There have been no previous studies of the association between the type of greenness and DNA methylation change, and further studies are needed to investigate the effect of exposure to various types of greenness and intelligence in children. The DNA methylation changes and greenness exposure still need to be analyzed in the entire EDC cohort rather than the sub-study [30].

Our study had several strengths. First, to our knowledge, this is the first epigenetic study of the association between greenness exposure and cognitive-ability-related DNA methylation changes in children. Second, we estimated the association between greenness exposure related to DNA methylation at age 2 and children's IQ at age 6 in a prospective cohort study, which might provide a clue to explain the causal role of greenness in neurodevelopment in children. Third, we estimated the proportions of greenness in buffers of various sizes and exposure to various types of greenness. There is currently insufficient evidence to determine which type of greenness exposure and which buffer size have the greatest impact on mental health in children, and further studies should be performed using buffers of various sizes and various types of greenness. 
However, our study has some limitations. First, we only had DNA methylation data of 59 children, not the entire EDC cohort, even though we found no significant differences in the characteristics of the children in the sub-cohort and the full EDC cohort; thus, our findings need to be further evaluated in a larger cohort. Second, we measured the surrounding greenness captured during a single period using satellite-derived land-cover maps without considering the period of greenness assessment. Third, we focused on residential surrounding greenness based on the residential addresses of our participants, which did not reflect their exposure level to greenness at other places, which may have caused exposure misclassification. Fourth, we were unable to evaluate participants' access to greenness due to the lack of information, so further study is needed to consider how children's exposure to greenness is related to their accessibility to greenness.

\section{Conclusions}

Surrounding greenness exposure at age 2 was associated with DNA methylation changes, and further associated with cognitive abilities. Further studies are warranted to clarify the epigenetic pathways linking greenness exposure and neurocognitive functions in children.

Supplementary Materials: The following are available online at https:/ / www.mdpi.com/article/10 .3390/ijerph18147429/s1: Table S1. Previous EWAS or GWAS studies for the association between DNA methylation and IQ. Table S2. List of target cg sites from previous EWAS $(n=209)$. Table S3. List of target cg sites from previous GWAS $(n=8534)$. Table S4. List of 20 top-ranked genes in Reactome pathway analysis. Table S5. Association between selected CpG sites and children's Total, Verbal, and Performance IQ $(n=59)$. Table S6. Association between DNA methylation level at cg26269038 and children's Total, Verbal, and Performance IQ $(n=59)$.

Author Contributions: Conceptualization, K.-S.L. and Y.-J.C.; methodology, J.-W.C.; software, S.-J.M.; validation, Y.-J.C.; formal analysis, K.-S.L.; investigation, Y.-H.L. and J.-I.K.; resources, Y.-A.L. and C.-H.S.; data curation, Y.-H.L.; writing-original draft preparation, K.-S.L. and Y.-J.C.; writingreview and editing, J.-I.K. and Y.-C.H.; visualization, K.-S.L.; supervision, Y.-C.H. and B.-N.K.; project administration, Y.-C.H.; funding acquisition, Y.-C.H. All authors have read and agreed to the published version of the manuscript.

Funding: The EDC study was supported by the Ministry of Environment through the Environmental Health Center Program of the Republic of Korea, and partially supported by grants from the Basic Science Research Program through the National Research Foundation of Korea, funded by the Ministry of Education (No. 2018R1D1A1B07043446).

Institutional Review Board Statement: The study protocol was approved by the Institutional Review Board of Seoul National University College of Medicine (IRB No. 1201-010-392).

Informed Consent Statement: Informed consent was obtained from the parents after a thorough explanation of the study.

Data Availability Statement: Not applicable.

Acknowledgments: The authors would like to thank Hyun Ji Lee and Jinah Park for data collection. The authors greatly appreciate the participation of the study volunteers and their parents. We would like to thank the Environmental Geographic Information Service for consulting on how to handle satellite images.

Conflicts of Interest: The authors declare no conflict of interest.

\section{References}

1. Amoly, E.; Dadvand, P.; Forns, J.; López-Vicente, M.; Basagaña, X.; Julvez, J.; Alvarez-Pedrerol, M.; Mark, J.; Nieuwenhuijsen, M.J.; Sunyer, J. Green and blue spaces and behavioral development in Barcelona schoolchildren: The BREATHE project. Environ. Health Perspect. 2014, 122, 1351-1358. [CrossRef]

2. Casey, J.A.; James, P.; Rudolph, K.E.; Wu, C.-D.; Schwartz, B.S. Greenness and birth outcomes in a range of Pennsylvania communities. Int. J. Environ. Res. Public Health 2016, 13, 311. [CrossRef] 
3. Dadvand, P.; de Nazelle, A.; Figueras, F.; Basagaña, X.; Su, J.; Amoly, E.; Jerrett, M.; Vrijheid, M.; Sunyer, J.; Nieuwenhuijsen, M.J. Green space, health inequality and pregnancy. Environ. Int. 2012, 40, 110-115. [CrossRef]

4. Markevych, I.; Thiering, E.; Fuertes, E.; Sugiri, D.; Berdel, D.; Koletzko, S.; Von Berg, A.; Bauer, C.-P.; Heinrich, J. A cross-sectional analysis of the effects of residential greenness on blood pressure in 10-year old children: Results from the GINIplus and LISAplus studies. BMC Public Health 2014, 14, 477. [CrossRef] [PubMed]

5. Fuertes, E.; Markevych, I.; von Berg, A.; Bauer, C.-P.; Berdel, D.; Koletzko, S.; Sugiri, D.; Heinrich, J. Greenness and allergies: Evidence of differential associations in two areas in Germany. J. Epidemiol. Community Health 2014, 68, 787-790. [CrossRef]

6. Kabisch, N.; van den Bosch, M.; Lafortezza, R. The health benefits of nature-based solutions to urbanization challenges for children and the elderly-A systematic review. Environ. Res. 2017, 159, 362-373. [CrossRef]

7. Cilluffo, G.; Ferrante, G.; Fasola, S.; Montalbano, L.; Malizia, V.; Piscini, A.; Romaniello, V.; Silvestri, M.; Stramondo, S.; Stafoggia, M.; et al. Associations of greenness, greyness and air pollution exposure with children's health: A cross-sectional study in Southern Italy. Environ. Health 2018, 17, 1-12. [CrossRef] [PubMed]

8. Dzhambov, A.M.; Markevych, I.; Lercher, P. Associations of residential greenness, traffic noise, and air pollution with birth outcomes across Alpine areas. Sci. Total Environ. 2019, 678, 399-408. [CrossRef] [PubMed]

9. Grigsby-Toussaint, D.S.; Chi, S.-H.; Fiese, B.H. Where they live, how they play: Neighborhood greenness and outdoor physical activity among preschoolers. Int. J. Health Geogr. 2011, 10, 66. [CrossRef] [PubMed]

10. Ward, J.S.; Duncan, J.S.; Jarden, A.; Stewart, T. The impact of children's exposure to greenspace on physical activity, cognitive development, emotional wellbeing, and ability to appraise risk. Health Place 2016, 40, 44-50. [CrossRef]

11. Wan, C.; Shen, G.Q.; Choi, S.J. Underlying relationships between public urban green spaces and social cohesion: A systematic literature review. City Cult. Soc. 2021, 24, 100383. [CrossRef]

12. Joubert, B.; Håberg, S.E.; Nilsen, R.M.; Wang, X.; Vollset, S.E.; Murphy, S.; Huang, Z.; Hoyo, C.; Midttun, Ø.; Uicab, L.C.; et al. 450K Epigenome-wide scan identifies differential DNA methylation in newborns related to maternal smoking during pregnancy. Environ. Health Perspect. 2012, 120, 1425-1431. [CrossRef]

13. Lee, K.W.K.; Richmond, R.; Hu, P.; French, L.; Shin, J.; Bourdon, C.; Reischl, E.; Waldenberger, M.; Zeilinger, S.; Gaunt, T.; et al. Prenatal exposure to maternal cigarette smoking and DNA methylation: Epigenome-wide association in a discovery sample of adolescents and replication in an independent cohort at birth through 17 years of Age. Environ. Health Perspect. 2015, 123, 193-199. [CrossRef] [PubMed]

14. Markunas, C.; Xu, Z.; Harlid, S.; Wade, P.; Lie, R.T.; Taylor, J.; Wilcox, A.J. Identification of DNA methylation changes in newborns related to maternal smoking during pregnancy. Environ. Health Perspect. 2014, 122, 1147-1153. [CrossRef] [PubMed]

15. Broberg, K.; Ahmed, S.; Engström, K.; Hossain, M.; Mlakar, S.J.; Bottai, M.; Grander, M.; Raqib, R.; Vahter, M. Arsenic exposure in early pregnancy alters genome-wide DNA methylation in cord blood, particularly in boys. J. Dev. Orig. Health Dis. 2014, 5, 288-298. [CrossRef] [PubMed]

16. Cardenas, A.; Koestler, D.C.; Houseman, E.A.; Jackson, B.P.; Kile, M.L.; Karagas, M.R.; Marsit, C.J. Differential DNA methylation in umbilical cord blood of infants exposed to mercury and arsenic in utero. Epigenetics 2015, 10, 508-515. [CrossRef]

17. Herbstman, J.B.; Tang, D.; Zhu, D.; Qu, L.; Sjödin, A.; Li, Z.; Camann, D.; Perera, F.P. Prenatal exposure to polycyclic aromatic hydrocarbons, benzo[a]pyrene-DNA adducts, and genomic DNA methylation in cord blood. Environ. Health Perspect. 2012, 120, 733-738. [CrossRef] [PubMed]

18. Khosla, S.; Dean, W.; Brown, D.; Reik, W.; Feil, R. Culture of preimplantation mouse embryos affects fetal development and the expression of imprinted genes. Biol. Reprod. 2001, 64, 918-926. [CrossRef]

19. Kingsley, S.L.; Eliot, M.N.; Whitsel, E.A.; Huang, Y.-T.; Kelsey, K.T.; Marsit, C.; Wellenius, G.A. Maternal residential proximity to major roadways, birth weight, and placental DNA methylation. Environ. Int. 2016, 92-93, 43-49. [CrossRef]

20. Gruzieva, O.; Xu, C.; Breton, C.V.; Annesi-Maesano, I.; Antó, J.M.; Auffray, C.; Ballereau, S.; Bellander, T.; Bousquet, J.; Bustamante, M.; et al. Epigenome-wide meta-analysis of methylation in children related to prenatal $\mathrm{NO}_{2}$ air pollution exposure. Environ. Health Perspect. 2017, 125, 104-110. [CrossRef]

21. Cao-Lei, L.; Very, F.; Elgbeili, G.; Szyf, M.; Laplante, D.P.; King, S. DNA methylation mediates the effect of exposure to prenatal maternal stress on cytokine production in children at age $13 \frac{1}{2}$ years: Project Ice Storm. Clin. Epigenet. 2016, 8, 1-15. [CrossRef] [PubMed]

22. Vidal, A.C.; Neelon, S.E.B.; Liu, Y.; Tuli, A.M.; Fuemmeler, B.; Hoyo, C.; Murtha, A.P.; Huang, Z.; Schildkraut, J.; Overcash, F.; et al. Maternal stress, preterm birth, and DNA methylation at imprint regulatory sequences in humans. Genet. Epigenet. 2014, 6 . [CrossRef]

23. Goodrich, J.; Dolinoy, D.C.; Sánchez, B.N.; Zhang, Z.; Meeker, J.D.; Mercado-Garcia, A.; Solano-González, M.; Hu, H.; Rojo, M.T.; Peterson, K.E. Adolescent epigenetic profiles and environmental exposures from early life through peri-adolescence. Environ. Epigenet. 2016, 2, dvw018. [CrossRef] [PubMed]

24. Bianco-Miotto, T.; Craig, J.M.; Gasser, Y.P.; Van Dijk, S.J.; Ozanne, S. Epigenetics and DOHaD: From basics to birth and beyond. J. Dev. Orig. Health Dis. 2017, 8, 513-519. [CrossRef]

25. Peng, C.; Dekker, M.D.; Cardenas, A.; Rifas-Shiman, S.L.; Gibson, H.; Agha, G.; Harris, M.H.; Coull, B.A.; Schwartz, J.; Litonjua, A.A.; et al. Residential proximity to major roadways at birth, DNA methylation at birth and midchildhood, and childhood cognitive test scores: Project Viva(Massachusetts, USA). Environ. Health Perspect. 2018, 126, 097006. [CrossRef] 
26. Marioni, R.E.; McRae, A.F.; Bressler, J.; Colicino, E.; Hannon, E.; Li, S.; Prada, D.; Smith, J.A.; Trevisi, L.; Tsai, P.-C.; et al. Meta-analysis of epigenome-wide association studies of cognitive abilities. Mol. Psychiatry 2018, 23, 2133-2144. [CrossRef] [PubMed]

27. Xu, R.; Li, S.; Li, S.; Wong, E.M.; Southey, M.C.; Hopper, J.L.; Abramson, M.J.; Guo, Y. Residential surrounding greenness and DNA methylation: An epigenome-wide association study. Environ. Int. 2021, 154, 106556. [CrossRef] [PubMed]

28. Peirce, T.R.; Bray, N.J.; Williams, N.M.; Norton, N.; Moskvina, V.; Preece, A.; Haroutunian, V.; Buxbaum, J.D.; Owen, M.J.; O'Donovan, M.C. Convergent evidence for $2^{\prime}, 3^{\prime}$-cyclic nucleotide $3^{\prime}$-phosphodiesterase as a possible susceptibility gene for schizophrenia. Arch. Gen. Psychiatry 2006, 63, 18-24. [CrossRef]

29. Rajkowska, G.; Mahajan, G.; Maciag, D.; Sathyanesan, M.; Iyo, A.H.; Moulana, M.; Kyle, P.B.; Woolverton, W.L.; Miguel-Hidalgo, J.J.; Stockmeier, C.A.; et al. Oligodendrocyte morphometry and expression of myelin-Related mRNA in ventral prefrontal white matter in major depressive disorder. J. Psychiatr. Res. 2015, 65, 53-62. [CrossRef] [PubMed]

30. Lee, K.-S.; Kim, B.-N.; Cho, J.; Jang, Y.-Y.; Choi, Y.-J.; Lee, W.-S.; Han, C.; Bae, H.-J.; Lim, Y.-H.; Kim, J.I.; et al. Associations between surrounding residential greenness and intelligence quotient in 6-year-old children. Sci. Total Environ. 2021, $759,143561$. [CrossRef] [PubMed]

31. Schoon, I.; Nasim, B.; Sehmi, R.; Cook, R. The Impact of Early Life Skills on Later Outcomes; OECD (Early Childhood Education and Care): Paris, France, 2015.

32. Kim, K.-N.; Lim, Y.-H.; Shin, C.H.; Lee, Y.A.; Kim, B.-N.; Kim, J.I.; Hwang, I.G.; Hwang, M.S.; Suh, J.-H.; Hong, Y.-C. Cohort Profile: The Environment and Development of Children (EDC) study: A prospective children's cohort. Int. J. Epidemiol. 2018, 47, 1049-1050f. [CrossRef]

33. Dial, G.; Bowen, H.; Gerlach, F.; Grodecki, J.; Oleszczuk, R. IKONOS satellite, imagery, and products. Remote Sens. Environ. 2003, 88, 23-36. [CrossRef]

34. Choi, Y.-J.; Lee, Y.A.; Hong, Y.-C.; Cho, J.; Lee, K.-S.; Shin, C.H.; Kim, B.-N.; Kim, J.I.; Park, S.J.; Bisgaard, H.; et al. Effect of prenatal bisphenol A exposure on early childhood body mass index through epigenetic influence on the insulin-like growth factor 2 receptor (IGF2R) gene. Environ. Int. 2020, 143, 105929. [CrossRef] [PubMed]

35. Teschendorff, A.E.; Marabita, F.; Lechner, M.; Bartlett, T.; Tegner, J.; Gomez-Cabrero, D.; Beck, S. A beta-mixture quantile normalization method for correcting probe design bias in Illumina Infinium $450 \mathrm{k}$ DNA methylation data. Bioinformatics 2012, 29, 189-196. [CrossRef]

36. Maechler, M. R Package Version 0.75-5. Available online: https://www.gbif.org/tool/81287/r-a-language-and-environment-forstatistical-computing\#citation (accessed on 30 May 2021).

37. Park, K.; Yoon, J.; Park, H.; Park, H.; Kwon, K. Development of KEDI-WISC, Individual Intelligence Test for Korean Children; Korea Educational Development Institute: Seoul, Korea, 1996.

38. Kim, J.I.; Hong, Y.-C.; Shin, C.H.; Lee, Y.A.; Lim, Y.-H.; Kim, B.-N. The effects of maternal and children phthalate exposure on the neurocognitive function of 6-year-old children. Environ. Res. 2017, 156, 519-525. [CrossRef]

39. Aryee, M.J.; Jaffe, A.E.; Corrada-Bravo, H.; Ladd-Acosta, C.; Feinberg, A.P.; Hansen, K.D.; Irizarry, R.A. Minfi: A flexible and comprehensive Bioconductor package for the analysis of Infinium DNA methylation microarrays. Bioinformatics 2014, 30, 1363-1369. [CrossRef] [PubMed]

40. Houseman, E.A.; Accomando, W.P.; Koestler, D.C.; Christensen, B.C.; Marsit, C.J.; Nelson, H.H.; Wiencke, J.K.; Kelsey, K.T. DNA methylation arrays as surrogate measures of cell mixture distribution. BMC Bioinform. 2012, 13, 86. [CrossRef] [PubMed]

41. Lim, Y.-R.; Lee, W.-K.; Lee, W.-H.; Park, J.-W. The study on the accuracy and validity of Korean Wechsler Intelligence Scale short forms: A comparison of the WARD7 subtest vs Doppelt subtest. Korean J. Clin. Psychol. 2000, 19, 563-574.

42. Johnson, W.; Li, C.; Rabinovic, A. Adjusting batch effects in microarray expression data using empirical Bayes methods. Biostatistics 2006, 8, 118-127. [CrossRef]

43. Akaike, H. A new look at the statistical model identification. IEEE Trans. Autom. Control 1974, 19, 716-723. [CrossRef]

44. Yu, G.; He, Q.-Y.J.M.B. ReactomePA: An R/Bioconductor package for reactome pathway analysis and visualization. Mol. Biosyst. 2016, 12, 477-479. [CrossRef]

45. Caramaschi, D.; Neumann, A.; Cardenas, A.; Tindula, G.; Alemany, S.; Zilich, L.; Pesce, G.; Lahti, J.M.T.; Havdahl, A.; Mulder, R.; et al. Meta-analysis of epigenome-wide associations between DNA methylation at birth and childhood cognitive skills. Biorxiv 2020. [CrossRef]

46. Caramaschi, D.; Sharp, G.C.; Nohr, E.A.; Berryman, K.; Lewis, S.J.; Smith, G.D.; Relton, C.L. Exploring a causal role of DNA methylation in the relationship between maternal vitamin $B_{12}$ during pregnancy and child's IQ at age 8 , cognitive performance and educational attainment: A two-step Mendelian randomization study. Hum. Mol. Genet. 2017, 26, 3001-3013. [CrossRef] [PubMed]

47. Krushkal, J.; Murphy, L.E.; Palmer, F.B.; Graff, J.C.; Sutter, T.R.; Mozhui, K.; Hovinga, C.A.; Thomas, F.; Park, V.; Tylavsky, F.A.; et al. Epigenetic analysis of neurocognitive development at 1 year of age in a community-based pregnancy cohort. Behav. Genet. 2014, 44, 113-125. [CrossRef]

48. Linnér, R.K.; Marioni, R.E.; Rietveld, C.A.; Simpkin, A.J.; Davies, N.; Watanabe, K.; Armstrong, N.J.; Auro, K.; Baumbach, C.; Bonder, M.J.; et al. An epigenome-wide association study meta-analysis of educational attainment. Mol. Psychiatry 2017, 22, 1680-1690. [CrossRef] [PubMed] 
49. Paquette, A.G.; Houseman, E.A.; Green, B.B.; Lesseur, C.; Armstrong, D.A.; Lester, B.; Marsit, C.J. Regions of variable DNA methylation in human placenta associated with newborn neurobehavior. Epigenetics 2016, 11, 603-613. [CrossRef] [PubMed]

50. Benyamin, B.; Pourcain, B.S.; Davis, O.; Davies, G.; Hansell, N.; Brion, M.-J.; Kirkpatrick, R.M.; Cents, R.A.M.; Franic, S.; Miller, M.B.; et al. Childhood intelligence is heritable, highly polygenic and associated with FNBP1L. Mol. Psychiatry 2014, 19, 253-258. [CrossRef]

51. Coleman, J.R.; Bryois, J.; Gaspar, H.A.; Jansen, P.R.; Savage, J.E.; Skene, N.; Plomin, R.; Muñoz-Manchado, A.B.; Linnarsson, S.; Crawford, G.; et al. Biological annotation of genetic loci associated with intelligence in a meta-analysis of 87,740 individuals. Mol. Psychiatry 2019, 24, 182-197. [CrossRef] [PubMed]

52. Hill, W.D.; Davies, G.; Van De Lagemaat, L.N.; Christoforou, A.; Marioni, R.; Fernandes, C.; Liewald, D.C.; Croning, M.D.R.; Payton, A.; Craig, L.C.A.; et al. Human cognitive ability is influenced by genetic variation in components of postsynaptic signalling complexes assembled by NMDA receptors and MAGUK proteins. Transl. Psychiatry 2014, 4, 1-8. [CrossRef] [PubMed]

53. Jansen, P.R.; Nagel, M.; Watanabe, K.; Wei, Y.; Savage, J.E.; De Leeuw, C.A.; Heuvel, M.P.V.D.; Van Der Sluis, S.; Posthuma, D. Genome-wide meta-analysis of brain volume identifies genomic loci and genes shared with intelligence. Nat. Commun. 2020, 11, 5606. [CrossRef]

54. Kong, L.; Cheng, L.; Fan, L.-Y.; Zhao, M.; Qu, H. IQdb: An intelligence quotient score-associated gene resource for human intelligence. Database 2013, 2013, bat063. [CrossRef]

55. Kornilov, S.; Tan, M.; Aljughaiman, A.; Naumova, O.; Grigorenko, E.L. Genome-wide homozygosity mapping reveals genes associated with cognitive ability in children from Saudi Arabia. Front. Genet. 2019, 10, 888. [CrossRef]

56. Savage, J.E.; Jansen, P.R.; Stringer, S.; Watanabe, K.; Bryois, J.; De Leeuw, C.A.; Nagel, M.; Awasthi, S.; Barr, P.B.; Coleman, J.R.I.; et al. Genome-wide association meta-analysis in 269,867 individuals identifies new genetic and functional links to intelligence. Nat. Genet. 2018, 50, 912-919. [CrossRef]

57. Luciano, M.; Wright, M.J.; Duffy, D.L.; Wainwright, M.A.; Zhu, G.; Evans, D.M.; Geffen, G.M.; Montgomery, G.W.; Martin, N.G. Genome-wide scan of IQ finds significant linkage to a quantitative trait locus on 2q. Behav. Genet. 2005, 36, 45-55. [CrossRef]

58. Smajlagić, D.; Jacobsen, K.K.; Myrum, C.; Haavik, J.; Johansson, S.; Zayats, T. Moderating effect of mode of delivery on the genetics of intelligence: Explorative genome-wide analyses in ALSPAC. Brain Behav. 2018, 8, e01144. [CrossRef]

59. Sniekers, S.; Stringer, S.; Watanabe, K.; Jansen, P.R.; Coleman, J.R.; Krapohl, E.; Taskesen, E.; Hammerschlag, A.R.; Okbay, A.; Zabaneh, D.; et al. Genome-wide association meta-analysis of 78,308 individuals identifies new loci and genes influencing human intelligence. Nat. Genet. 2017, 49, 1107-1112. [CrossRef] [PubMed]

60. Zabaneh, D.; Krapohl, E.; Gaspar, H.; Curtis, C.; Lee, S.H.; Patel, H.; Newhouse, S.; Wu, H.M.; Simpson, M.A.; Putallaz, M.; et al. A genome-wide association study for extremely high intelligence. Mol. Psychiatry 2018, 23, 1226-1232. [CrossRef] [PubMed]

61. Zhao, M.; Kong, L.; Qu, H. A systems biology approach to identify intelligence quotient score-related genomic regions, and pathways relevant to potential therapeutic treatments. Sci. Rep. 2014, 4, 4176. [CrossRef] [PubMed]

62. Zhu, Z.; Chen, B.; Yan, H.; Fang, W.; Zhou, Q.; Zhou, S.; Lei, H.; Huang, A.; Chen, T.; Gao, T.; et al. Multi-level genomic analyses suggest new genetic variants involved in human memory. Eur. J. Hum. Genet. 2018, 26, 1668-1678. [CrossRef] [PubMed]

63. Feil, R.; Fraga, M.F. Epigenetics and the environment: Emerging patterns and implications. Nat. Rev. Genet. 2012, 13, 97-109. [CrossRef] [PubMed]

64. Reik, W. Stability and flexibility of epigenetic gene regulation in mammalian development. Nat. Cell Biol. 2007, 447, 425-432. [CrossRef] [PubMed]

65. Young, L.E.; Fernandes, K.; McEvoy, T.G.; Butterwith, S.C.; Gutierrez, C.G.; Carolan, C.; Broadbent, P.J.; Robinson, J.J.; Wilmut, I.; Sinclair, K.D. Epigenetic change in IGF2R is associated with fetal overgrowth after sheep embryo culture. Nat. Genet. 2001, 27, 153-154. [CrossRef] [PubMed]

66. Chen, N.-H.; Reith, M.E.A.; Quick, M.W. Synaptic uptake and beyond: The sodium- and chloride-dependent neurotransmitter transporter family SLC6. Pflügers Arch. 2004, 447, 519-531. [CrossRef] [PubMed]

67. Fuke, S.; Suo, S.; Takahashi, N.; Koike, H.; Sasagawa, N.; Ishiura, S. The VNTR polymorphism of the human dopamine transporter (DAT1) gene affects gene expression. Pharmacogenom. J. 2001, 1, 152-156. [CrossRef]

68. Vandenbergh, D.; Thompson, M.; Cook, E.; Bendahhou, E.; Nguyen, T.; Krasowski, M.; Zarrabian, D.; Comings, D.; Sellers, E.M.; Tyndale, R.F.; et al. Human dopamine transporter gene: Coding region conservation among normal, Tourette's disorder, alcohol dependence and attention-deficit hyperactivity disorder populations. Mol. Psychiatry 2000, 5, 283-292. [CrossRef] [PubMed]

69. Cómbita, L.M.; Voelker, P.; Abundis-Gutiérrez, A.; Pozuelos, J.P.; Rueda, M.R. Influence of the SLC6A3-DAT1 gene on multifaceted measures of self-regulation in preschool children. Front. Psychol. 2017, 8, 26. [CrossRef]

70. Kaminski, J.A.; Schlagenhauf, F.; Rapp, M.; Awasthi, S.; Ruggeri, B.; Deserno, L.; Banaschewski, T.; Bokde, A.L.W.; Bromberg, U.; Büchel, C.; et al. Epigenetic variance in dopamine D2 receptor: A marker of IQ malleability? Transl. Psychiatry $2018,8,169$. [CrossRef]

71. Montague, P.R.; Hyman, S.E.; Cohen, J.D. Computational roles for dopamine in behavioural control. Nat. Cell Biol. 2004, 431, 760-767. [CrossRef] [PubMed]

72. Schlagenhauf, F.; Rapp, M.A.; Huys, Q.; Beck, A.; Wüstenberg, T.; Deserno, L.; Buchholz, H.; Kalbitzer, J.; Buchert, R.; Bauer, M.; et al. Ventral striatal prediction error signaling is associated with dopamine synthesis capacity and fluid intelligence. Hum. Brain Map. 2013, 34, 1490-1499. [CrossRef]

73. Figlewicz, D.P. Endocrine regulation of neurotransmitter transporters. Epilepsy Res. 1999, 37, 203-210. [CrossRef] 
74. Yeager, R.; Riggs, D.W.; DeJarnett, N.; Tollerud, D.J.; Wilson, J.; Conklin, D.J.; O’Toole, T.E.; McCracken, J.; Lorkiewicz, P.; Xie, Z.; et al. Association between residential greenness and cardiovascular disease risk. J. Am. Heart Assoc. 2018, 7, e009117. [CrossRef] [PubMed]

75. De Petris, S.; Squillacioti, G.; Bono, R.; Borgogno-Mondino, E. Geomatics and epidemiology: Associating oxidative stress and greenness in urban areas. Environ. Res. 2021, 197, 110999. [CrossRef] [PubMed]

76. Squillacioti, G.; Carsin, A.E.; Borgogno-Mondino, E.; Bono, R.; Aymerich, J.G. Greenness and physical activity as possible oxidative stress modulators in children. Eur. J. Public Health 2020, 30, ckaa165.090. [CrossRef]

77. Squillacioti, G.; Bellisario, V.; Ghelli, F.; Piccioni, P.; Bono, R. Greenness effect on oxidative stress and respiratory flows in children. Environ. Epidemiol 2019, 3, 35-36.

78. Salim, S. Oxidative Stress and the Central Nervous System. J. Pharmacol. Exp. Ther. 2016, 360, 201-205. [CrossRef] [PubMed]

79. Herman, F.; Westfall, S.; Brathwaite, J.; Pasinetti, G.M. Suppression of presymptomatic oxidative stress and inflammation in neurodegeneration by grape-derived polyphenols. Front. Pharmacol. 2018, 9, 867. [CrossRef] [PubMed]

80. Volf, N.V.; Sinyakova, N.A.; Osipova, L.P.; Kulikov, A.V.; Belousova, L.V. Association between intelligence quotient and the 5HTTLPR polymorphism of human serotonin transporter coding gene. J. Psychiatry Brain Funct. 2015, 2, 8. [CrossRef]

81. Kunugi, H.; Hattori, M.; Kato, T.; Tatsumi, M.; Sakai, T.; Sasaki, T.; Hirose, T.; Nanko, S. Serotonin transporter gene polymorphisms: Ethnic difference and possible association with bipolar affective disorder. Mol. Psychiatry 1997, 2, 457-462. [CrossRef]

82. Gelernter, J.; Kranzler, H.; Cubells, J.F. Serotonin transporter protein (SLC6A4) allele and haplotype frequencies and linkage disequilibria in African-and European-American and Japanese populations and in alcohol-dependent subjects. Hum. Genet. 1997, 101, 243-246. [CrossRef]

83. Nakamura, M.; Ueno, S.; Sano, A.; Tanabe, H. The human serotonin transporter gene linked polymorphism (5-HTTLPR) shows ten novel allelic variants. Mol. Psychiatry 2000, 5, 32-38. [CrossRef]

84. Breton, C.V.; Marsit, C.J.; Faustman, E.; Nadeau, K.; Goodrich, J.M.; Dolinoy, D.C.; Herbstman, J.; Holland, N.; LaSalle, J.M.; Schmidt, R.; et al. Small-magnitude effect sizes in epigenetic end points are important in children's environmental health studies: The children's environmental health and disease prevention research center's epigenetics working group. Environ. Health Perspect. 2017, 125, 511-526. [CrossRef] [PubMed]

85. Murphy, S.K.; Adigun, A.; Huang, Z.; Overcash, F.; Wang, F.; Jirtle, R.L.; Schildkraut, J.M.; Murtha, A.P.; Iversen, E.S.; Hoyo, C. Gender-specific methylation differences in relation to prenatal exposure to cigarette smoke. Gene 2012, 494, 36-43. [CrossRef] [PubMed] 